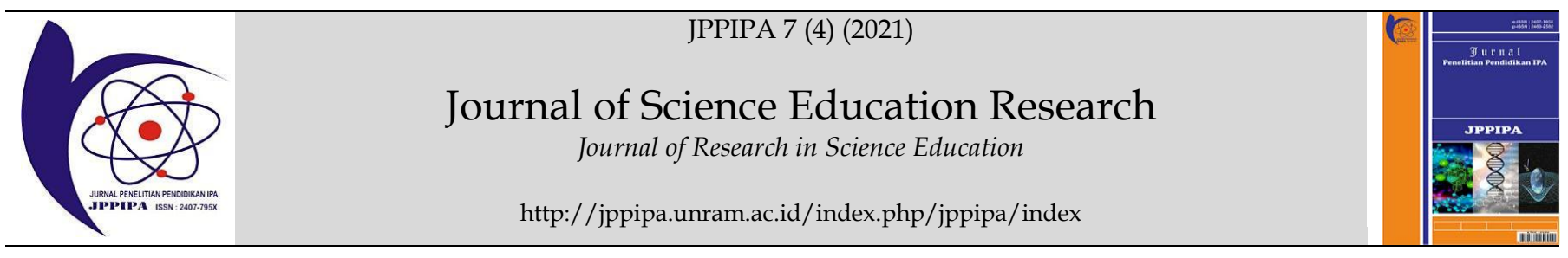

\title{
Analysis of the Relationship of Multiple Intelligences and Learning Interests with Biology Learning Outcomes
}

\author{
Kiki Mulyani1 ${ }^{*}$, Ramadhan Sumarmin ${ }^{1}$, Yuni Ahda ${ }^{1}$, Heffi Alberida ${ }^{1}$, Abdul Razak ${ }^{1}$ \\ ${ }^{1}$ Biology Department, Master's Degree Program of Biology Education, Universitas Negeri Padang, Padang, Indonesia
}

DOI: $\underline{10.29303 / \text { ippipa.v7i4.774 }}$

\section{Article Info}

Received: May 31th, 2021

Revised: September 15th, 2021

Accepted: September 22th, 2021

\begin{abstract}
Student learning outcomes have not reached the minimum completeness criteria. Teachers have not measured the level of Multiple Intelligences (MI) and the student's interest in learning. The learning process is still teacher-centered. This is the problem facing the world of education in the 21st century. Efforts to overcome this problem are by measuring the relationship between MI and interest in learning biology with student learning outcomes. This study aims to determine the relationship between MI as a whole and the interest in learning collectively on students' learning outcomes in Biology subjects in class X Mathematics and Natural Sciences SMA Negeri in Padang City. This research is a descriptive study that was conducted in March-April at the public high schools in Padang City for the 2020/2021 school year. The sample was taken using a purposive, random sampling technique and obtained a sample of 297 students spread across five public schools in Padang. The research instrument used the questionnaire MI, the interest in learning questionnaire, and the question HOTS. The data in this study were analyzed using multiple correlations. The results showed that there was a close relationship between MI and interest in learning with the results of studying biology class X MIPA SMAN in the city of Padang.
\end{abstract}

Keywords: Multiple Intelligences; Learning Interests; Biology Learning Outcomes.

Citation: Mulyani, K., Sumarmin, R., Ahda, Y., Alberida, H., \& Razak, A. (2021). Analysis of the Relationship of Multiple Intelligences and Learning Interests with Biology Learning Outcomes. Jurnal Penelitian Pendidikan IPA, 7(4), 531536. doi:https://doi.org/10.29303/jppipa.v7i4.774

\section{Introduction}

The 21st century is a challenge in the world of education. Usman et al. (2021) stated that teachers are the foundation in improving the quality of education in the 21st century. Education is certainly inseparable from the learning process, where there is an interaction between students and teachers as educators. According to Hall (2016), interaction is a reciprocal relationship (feedback) between one individual and another who exchanges conversations and occurs in the community. In the learning process, interactions occur between teachers and students. The interaction between teachers and students will increase and affect the learning outcomes of students. Pane and Dasopang (2017) state that the learning process's success is generally seen from the learning outcomes achieved by students. The problem that is often faced in the learning process is the low learning outcomes obtained by students. High or low learning outcomes can be influenced by several factors, which include: 1) internal factors (factors that come from within the individual), and 2) external factors (factors originating from outside the individual). Internal factors that affect student learning outcomes are intelligence, interests, talents, physical health, motivation, and learning styles. The family, community, and school environment are influential aspects (Taiyeb et al., 2015). Internal factors that affect

\footnotetext{
*Email: ikimulyani@gmail.com
} 
learning outcomes are intelligence and interest in learning. Gardner in Rofiah (2016) states that intelligence can not only be assessed from academic tests or only IQ tests, but intelligence is about a person's ability to find solutions or solve a problem. Each individual has different types of intelligence other than those that can be assessed from academia alone (Huda, 2017).

Armstrong in Winarti et al. (2019) states that the various kinds of intelligence possessed by each individual consist of nine levels of intelligence and are known as Multiple Intelligences. Internal factors that affect learning outcomes other than intelligence are the interests of students. The educational process is closely related to interest. Interests are able to provide benefits and bring satisfaction to students. According to Nurhasanah (2016), interest affects three important aspects of a person's knowledge: attention, goals, and learning levels. The level of interest in learning students in biology lessons will also affect the biology learning outcomes of students. Alwahidi et al. (2021) stated that students' interest in learning could be seen through the behavior of these students during the learning process. There is a significant influence between learning interest and learning achievement in mathematics. This can be seen from the efficient task correlation between learning interest and learning achievement of 0.706 and falls into a strong category. Thus, there is a positive relationship between learning outcomes and interest in learning (Sirait, 2016).

In classroom learning, each subject has different difficulties for students. Therefore, students must be able to acquire, process, and make use of this knowledge proportionally. The ability to obtain, process, and utilize students can develop this by exploring the dominant intelligence in themselves and their learning interests. This can be seen when researchers make field observations. At the time of the learning process in class, it was seen that not all of the students participated actively during the learning process. The students did not seem interested in participating in in-class learning.

The observation data reveals that students' learning styles, which the dominant intelligence, can affect the learning interest. This is because the learning method that is not in accordance with students' learning styles in a heterogeneous class in the classroom makes students not interested in following the learning that is taking place. Only a small proportion of students who have a high interest in learning and in accordance with their learning style are seen to be active in the learning process.

Some students do not do assignments, and some do not follow the learning process in the learning process. Learning like this becomes an obstacle for teachers to monitor students directly and affects students' learning outcomes under the minimum completeness criteria. Sultan (2017) states that there is a correlation between the attitudes and learning outcomes of students taught with the approach MI through the direct learning model of class XI IPA SMA Negeri 11 Makassar.

This problem can be prevented if teachers and students can find out the level of MI and students' interest in learning Biology. Musfiroh in Jumiatin et al. (2020) states that by knowing the level of MI students, teachers can find out special moments and teaching strategies that can be used to prepare lesson plans, and their implementation in the learning process foster interest in learning from students. In addition, teachers can monitor the development of students and help develop the potential of students so that students become more confident and student learning outcomes are as expected. Therefore, this study aimed to determine the relationship between MI and interest in learning together in influencing the learning outcomes of students' biology.

\section{Method}

This research is a quantitative study with an approach correlational study. In this study, a dependent variable is connected in the form of biology learning outcomes of students with two independent variables in the form of MI and interest in learning biology. The population in this study was a student of class X MIPA at State High School in Kota Padang academic year 2020/2021. The study sample amounted to 297 students randomly distributed at five public high schools in Padang City. The study sample was obtained using the purposive proportional random sampling technique.

The data MI of students was measured using an instrument in the form of an MI questionnaire consisting of 69 questions for nine levels. The students' learning interest data used a learning interest questionnaire instrument with 22 questions. The questionnaire on the data collection instrument MI uses a Likert scale with four alternative answers to the questions given, namely $\mathrm{Al}$ (Always), Oft (Often), $\mathrm{Rr}$ (Rarely), and Nv (Never). Each alternative answer has a value of 4,3,2, and 1. Questionnaires are useful for knowing the level of MI and the learning interest of students. The instrument used in this study has been tested for validity and reliability before use.

The data on students' biology learning outcomes used a research instrument in the form of high order thinking skills with materials on fungi, Plantae, and 
Animalia, which were spread over 40 items and tested for validity, difficulty level, differentiation, and questions. The data analysis technique used is descriptive statistical techniques. To see the relationship between the three data variables, the multiple correlation formula $(\mathrm{R})$ is used, a number that shows the direction and strength of the relationship between two independent variables and one dependent variable.

\section{Result and Discussion}

A multiple correlation formula is used to find out the relationship between MI and interest in learning biology with students' learning outcomes in class $\mathrm{X}$ Mathematics and Natural Sciences in SMA Negeri in Padang,. The results of the calculation of the relationship between $\mathrm{mi}$ as a whole and interest in learning biology with the results of student biology learning can be seen in Table 1 .

Table 1: Data Correlation Test Results MI Overall and Biology Learning Interests with Students' Biology Learning Outcomes

\begin{tabular}{|c|c|c|c|c|c|}
\hline \multicolumn{3}{|l|}{ Variable } & \multirow{2}{*}{$\begin{array}{l}\text { School } \\
\text { SMAN } 2\end{array}$} & \multirow{2}{*}{$\begin{array}{l}\text { Coefficient } \\
\text { Correlation }\end{array}$} & \multirow{2}{*}{$\begin{array}{l}\text { Criteria } \\
\text { Correlation } \\
\text { Strong }\end{array}$} \\
\hline MI $\left(X_{1}\right)$ & Interest in Biology & Learning Outcomes & & & \\
\hline & Learning $\left(\mathrm{X}_{2}\right)$ & of Biology (Y) & SMAN 3 & 0.85 & Strong \\
\hline & & & SMAN 9 & 0.87 & Strong \\
\hline & & & SMAN 10 & 0.89 & Strong \\
\hline & & & SMAN 13 & 0.89 & Strong \\
\hline & & & School in Padang City & 0.82 & Strong \\
\hline
\end{tabular}

Value $\mathrm{r}+$ (positive) and - (negative) provide information about the direction of the relationship between two variables. Suppose the value is + (positive). In this case, the two variables have a unidirectional relationship. This means that the increase in variable $X$ will coincide with the increase in variable Y. If - (negative), the correlation between the two variables is opposite. This means that a decrease will follow the increase in variable $\mathrm{X}$ in variable $\mathrm{Y}$.
Correlation criteria between MI as a whole and interest in studying biology with student learning outcomes in class X Mathematics and Natural Sciences of Padang State High School have strong criteria on average.

Determinant coefficients and the t-test MI overall and interest in learning biology with the biology learning outcomes of students can be seen in Table

Table 2: Determination Coefficients and t-test MI Overall and Biology Learning Interests with Students' Biology learning outcomes

\begin{tabular}{|c|c|c|c|c|c|}
\hline Variable & & & School & $\begin{array}{l}\text { Coefficient } \\
\text { Determinants (\%) }\end{array}$ & $t_{\text {count }}$ \\
\hline \multirow[t]{6}{*}{$\operatorname{MI}\left(X_{1}\right)$} & Interest in Biology & Learning Outcomes & SMAN 2 & 64.49 & 11.27 \\
\hline & Learning $\left(\mathrm{X}_{2}\right)$ & of Biology (Y) & SMAN 3 & 72.33 & 13.52 \\
\hline & & & SMAN 9 & 76.28 & 12.43 \\
\hline & & & SMAN 10 & 79.66 & 16.55 \\
\hline & & & SMAN 13 & 78.60 & 10.32 \\
\hline & & & $\begin{array}{l}\text { Senior High School in } \\
\text { Padang City }\end{array}$ & 66.63 & 24.27 \\
\hline
\end{tabular}

Based on Table 2, it can be seen that the results of the determinant coefficient tests on some correlation between Multiple Intelligences as a whole and learning interests in each school had the highest influence, which was $79.66 \%$ affecting learning outcomes, while the lowest score was $64.49 \%$ affecting learning outcomes. Furthermore, to determine whether there is a significant relationship between the Multiple Intelligences as a whole and the interest in learning with learning outcomes, the t-test is used. Based on the results of the t-test seen that $t_{\text {arithmetic }}>t_{\text {table, }}$ it can be, so it can be concluded that the interest in learning has a significant relationship with learning outcomes.

Based on the research results that have been analyzed, MI and students' interest in learning towards learning outcomes of students in class X MIPA SMA Negeri In the city of Padang both have a strong correlation with learning outcomes in general. This is evidenced by the value of the correlation analysis MI and interest in learning with the biology learning outcomes of students is 0.8163 . This means that it can be assumed that the increasing MI and the interest in 
learning of students simultaneously will have a strong influence on the increase in learning outcomes for students of class X MIPA SMA Negeri in the city of Padang.

Based on the results of the data analysis MI and learning interest with the biology learning outcomes of class X MIPA students of SMA Negeri in the city of Padang, there is a significant relationship between the level MI and students' interest in learning with biology learning outcomes. This can be seen from the value of $t_{\text {count }}$ (24.271), which is greater than the value of $t_{\text {table }}$ (1.650). The coefficient of determination is $66.632 \%$. This means that MI and interest in learning simultaneously will affect student learning outcomes. Besides being influenced by MI and interest in learning, $33.368 \%$ are influenced by factors outside MI and interest in learning. According to Ardilla (2017), factors that affect student learning outcomes, namely, student interest in the lesson, student concentration during the learning process, students' understanding of concepts, and student discipline.

The results of the analysis at each school show that at SMAN 2, 3, 9, 10, and 13 Padang, it is also known that the correlation between MI and interest in learning with student learning outcomes has a strong correlation value with an average correlation value of 0.8612 . So that the increasing $\mathrm{MI}$ and interest in learning owned by students at SMAN 2, 3, 9, 10, and 13 Padang will have a strong influence on the increase in learning outcomes of students' biology, this can be seen from the value of $t_{\text {arithmetic }}$ which is greater in SMAN 2, $3,9,10$ and 13 Padang than the $t_{\text {table }}$.

The determining coefficient of MI and interest in learning with the biology learning outcomes of students in each school, namely SMAN 2, 3, 9, 10, and 13 respectively, were $64.490 \%$; $72.333 \%$; 76,278\%; $79,660 \%$; and $78.604 \%$. Besides being influenced by MI and interest in learning, learning outcomes are also influenced by other factors. According to Ardilla (2017), factors that affect student learning outcomes, namely, student interest in the lesson, student concentration during the learning process, students' understanding of concepts, and student discipline. According to Hartshorne (2015), human thinking will develop better with age. The more developed a person's thinking, the better that someone will judge himself. Students who can assess themselves are able to measure their abilities and intelligence.

In general, MI and interest in learning have a strong influence by increasing learning outcomes in students. Rofiah (2016) states that with the development of the concept MI and the acceptance of this theory in the world of education, it is inevitable that educators need to help children's growth and development in planning, implementing, and evaluating programs that provide a platform for the development of all types of their intelligence. The research of Herlina et al. (2018) states a positive and significant influence between intellectual intelligence and interest in learning on student learning achievement, so there is a need for efforts to increase intellectual intelligence and interest in learning together continuously.

Teachers need to pay attention to the interests and levels of MI that dominate students. By knowing both of them simultaneously, the teacher can optimize the learning process so that students can explore their potential and students' higher-order thinking skills can be well-honed to solve global challenges later. Baharuddin and Febriani (2020) state that-based learning HOTS needs to be integrated with the dominance of intelligence in students so that students' interest in participating in the learning process also increases. Sholiah revealed this (2020), namely, students who have high-order thinking skills must be able to connect something they see in their daily life and must be able to draw conclusions to solve problems well.

Ege (2016) also states that students' different levels of MI affect the high or low learning outcomes obtained by students. Leonard and Linda (2018) stated that higher-order thinking skills collaborate with the ability of the left brain and right brain to think, as an observer in a problem using the left brain and as a solution to think broadly using the right brain. According to Ahmad (2020), the provision oflearning and assessment HOTS will affect students' critical and creative thinking, where students will be invited to develop and train their high-level thinking skills in solving a problem.

Sholiah et al. (2019) stated that not all students master the nine bits of intelligence, but a student can have more than one dominant intelligence. In line with this, every teacher must be able to facilitate the development of each intelligence possessed by students. These students' learning outcomes increase and even increase students' higher-order thinking skills as a demand in the 21st century. Putri et al. (2021) stated that in the 21st century, students must have higher order thinking skills (HOTS), the ability to argue, literacy skills, and so on. Anggraeni et al. (2020) stated that in improving HOTS-based learning outcomes, teachers need first to understand HOTSbased learning to improve assessment tools such as student exam questions. 


\section{Conclusion}

The results of the study concluded that there was a close relationship between MI and interest in learning with the learning outcomes of students. This is evidenced by the value of the correlation analysis MI and interest in learning with the biology learning outcomes of students is 0.816 . Teachers need to pay attention to the interests and levels of MI that dominate students. This is because by knowing both of them simultaneously, the teacher can optimize the learning process so that students can explore their potential and students' high-level thinking skills can be properly validated to solve global challenges later.

\section{Acknowledgments}

Big Thank to Postgraduate Biology program, Department of Natural Sciences, this research was supported, which has facilitated the study. Researchers are also grateful to the biology subject teacher at the Public High School in Padang City for carrying out research well.

\section{References}

Ahmad, D.N. (2020). Analisis Sistem Penilaian Hots (Higher Order Thinking Skills) Dalam Mengukur Kemampuan Berpikir Kritis Dan Kreatif. BIOTIK: Jurnal Ilmiah Biologi Teknologi Dan Kependidikan, $8(1)$, 11. doi: https:// doi.org/10.22373/biotik.v8i1.6600 [Indonesian]

Alwahidi, A.A., Sani, M.I., Dewi., A.M., Darmawangsa, S.S., Alawiyah, T.N., Rohimah, S., Zahratul, I., Hasmiati, W., Mustapida, H., \& Sukenti, K. (2021). Optimalisasi Minat Belajar dengan Metode Fun Learning pada Era New Normal di Desa Sengkerang, Kecamatan Praya Timur. Jurnal Pengabdian Magister Pendidikan IPA, 4(2), 120-123.

doi:

https://doi.org/10.29303/ipmpi.v4i2.682

[Indonesian]

Anggraeni, D.M., \& Sole, F.B. (2020). Analysis of Science Teachers' Understanding of High Order Thinking Skills (HOTS) and Their Implementation in Learning. Jurnal Penelitian Pendidikan IPA (JPPIPA). 6(2). 210-214. doi:https:// doi.org/10.29303/jppipa.v6i2.411

Ardilla, A., \& Suryo, H. 2017. Faktor yang Mempengaruhi Rendahnya Hasil Belajar Matematika Siswa MTS Iskandar Muda Batam. Pythagoras, 6(2): 175-186. doi: https://doi.org/10.33373/pythagoras.v6i2.966

[Indonesian]

Ege, B., Supriandi, M.I., \& Ridho, D.A.S. (2016). Hubungan Antara Multiple Intelligences Dengan Hasil Belajar Kognitif Siswa Pada Mata Pelajaran Ilmu Pengetahuan Alam. In Prosiding Seminar Pendidikan IPA. 1(2), 863-872. [Indonesian]

Febriani, S.R. (2020). Analisis Implementasi Pembelajaran Bahasa Arab di Sekolah Dasar : HOTS, MOTS , LOTS ? Prosiding Konferensi Nasional Bahasa Arab VI (KONASBARA), 20, 432444. [Indonesian]

Hall, J.A. (2018). When is social media use social interaction? Defining mediated social interaction. New Media and Society, 20(1), 162-179. doi:https://doi.org/10.1177/1461444816660782

Hartshorne, J.K., \& Germine, L.T. (2015). When Does Cognitive Functioning Peak? The Asynchronous Rise and Fall of Different Cognitive Abilities Across the Life Span. Psychological Science, 26(4), 433-443. doi: https://doi.org/10.1177/0956797614567339

Huda, N., \& Agus, M. (2017). Pengaruh Adversity Quotient terhadap Prestasi Akademik Mahasiswa Angkatan 2013 Fakultas Psikologi UIN SGD Bandung. Psympathic. 4(1). doi:https:// doi.org/10.155575/psy.v4i1.1336 [Indonesian]

Jumiatin, K., Candra, A.W., \& Agus, S. (2020). Penerapan Metode Holistik Integratif dalam Meningkatkan Kecerdasan Interpersonal Anak Usia Dini di Purwakarta.Tunas Siliwangi: Jurnal Program Studi Pendidikan Guru PAUD. 6(2). doi: https://doi.org/10.22460/ts.v6i2p\%25p.1715 [Indonesian]

Leonard, L., \& Linda, N.N. (2018). Pengaruh Kecerdasan Logis-Matematis dan Kecerdasan Musikal Terhadap Higher Order Thinking Skills (Hots). KALAMATIKA Jurnal Pendidikan Matematika, 3(2), 193-208. doi: https://doi.org/10.22236/kalamatika.vol3no2.20 18pp193-208 [Indonesian]

Nurhasanah, S., \& Sobandi, A. 2016. Minat Belajar Sebagai Determinan Hasil Belajar Siswa. Jurnal Pendidikan Manajemen Perkantoran, 1(1), 128-135. doi: $\quad$ https://doi.org/10.17509/jpm.v1i1.3264 [Indonesian]

Putri, W., Sunarno, W., \& Marzuki, A. (2021). Analysis of The Students' Argumentative Skills of Senior High School in Covid-19 Pandemic using Problem Based Learning in Static Fluid. Jurnal Penelitian Pendidikan IPA, 7(3), 335-343. doi: https:// doi.org/10.29303/jppipa.v7i3.735 
Rofiah, N. H. (2016). Menerapkan multiple intelligences dalam pembelajaran di sekolah dasar. Jurnal Dinamika Pendidikan Dasar, 8(1), 69-79. Retrieved from http://jurnalnasional.ump.ac.id/index.php/Din amika/article/view/937/875 [Indonesian]

Safitri, I., Bancong, H., \& Husain, H. (2013). Pengaruh pendekatan multiple intelligences melalui model pembelajaran langsung terhadap sikap dan hasil belajar kimia peserta didik di sma negeri i tellu limpoe. Jurnal Pendidikan IPA Indonesia, 2(2), 156160. doi: https://doi.org/10.15294/jpii.v2i2.2717 [Indonesian]

Sholiah, U., Saefudin, \& Priyandoko, D. (2020). The Relationship Between Multiple Intelligences with Higher-Order Thinking Skills. International Conference on Elementary Education, 2, 257-269. Retrieved from http://proceedings.upi.edu/index.php/icee/art icle/view $/ 627 \% 0 \mathrm{~A}$

Sirait, E. D. (2016). Pengaruh Minat Belajar Terhadap Prestasi Belajar Matematika. Formatif: Jurnal Ilmiah Pendidikan MIPA, 6(1), 35-43. doi: https:// doi.org/10.30998/formatif.v6i1.750

Sukma, F. M., \& Sutarni, N. (2018). Pengaruh Manajemen Sumber Daya Berbasis Iso 9001:2008 Terhadap Kinerja Guru. Jurnal Pendidikan Manajemen Perkantoran, 3(2), 99. doi: https://doi.org/10.17509/jpm.v3i2.11770 [Indonesian]

Taiyeb, A. M., \& Mukhlisa, N. (2015). Hasil Belajar Biologi Siswa Kelas XI IPA SMA Negeri 1 Tanete Rilau. Jurnal Bionature, 16(1), 8-16. http://ojs.unm.ac.id/bionature/article/viewFile /1563/627 [Indonesian]

Usman, M.H., Al Idrus, A., Doyan, A., Soeprianto, H., \& Hakim, A. (2021). Teacher Basic Skills in Learning Science in Junior High Schools Facing the 21st Century. Jurnal Penelitian Pendidikan IPA, 7(3), 331-334. doi: https://doi.org/10.29303/ippipa.v7i3.652

Winarti, A., Yuanita, L., \& Nur, M. (2019). The Effectiveness of Multiple Intelligences Based Teaching Strategy in Enhancing the Multiple Intelligences and Science Process Skills of Junior High School Students. Journal of Technology and Science Education. 9(2). 122-135. doi: http://dpi.org/10.3926/jotse.404 